\title{
27. PERMEABILITY MEASUREMENTS IN HOLE 896A AND IMPLICATIONS FOR THE LATERAL VARIABILITY OF UPPER CRUSTAL PERMEABILITY AT SITES 504 AND 896
}

\author{
Keir Becker ${ }^{2}$
}

\begin{abstract}
A drill-string packer was used during Leg 148 to conduct measurements of the bulk permeabilities of three depth intervals in the upper crustal section penetrated by Hole 896A. Located about $1 \mathrm{~km}$ southeast of Hole 504B, near a local heat-flow high, Hole $896 \mathrm{~A}$ is cased through $179 \mathrm{~m}$ of sediment and the top $16 \mathrm{~m}$ of basement, and then penetrates to $469 \mathrm{mbsf}$, or $290 \mathrm{~m}$ into the upper oceanic crust. The packer was set in casing at $106 \mathrm{mbsf}$ and in open hole at 233 and $385 \mathrm{mbsf}$, and standard slug and constant-rate injection tests were conducted to assess the transmissivities and bulk permeabilities of the respective intervals $195-469,223-469$, and $385-469 \mathrm{mbsf}$. The results indicate that the upper $38 \mathrm{~m}$ of open hole is quite permeable, on the order of $2 \times 10^{-13} \mathrm{~m}^{2}$. The section below this zone, 223-469 mbsf, is less permeable, on the order of $1-2 \times 10^{-14} \mathrm{~m}^{2}$, but certainly permeable enough to support passive off-axis hydrothermal circulation. The permeability structure in Hole 896A is quite consistent with values determined in the upper $\approx 200 \mathrm{~m}$ of basement in Hole $504 \mathrm{~B}$, and supports the inference that the uppermost basement is permeable on a scale of kilometers around the sites. However, the measurements in Hole 896A show no sign of the sharp reduction in permeability previously reported below $\approx 250 \mathrm{~m}$ into basement in Hole 504B.
\end{abstract}

\section{INTRODUCTION}

Permeability, and its three-dimensional variation, is almost certainly the most important physical parameter controlling the patterns of circulation in an off-axis hydrothermal system, such as that on the southern flank of the Costa Rica Rift revisited for drilling during Ocean Drilling Program (ODP) Leg 148. However, it is difficult to directly determine the permeability of the oceanic crust and sediments and their scales of variability by any remote means. To date, the most reliable information about ocean crustal permeability comes from measurements made with drill-string packers in a few wellstudied reentry holes drilled by the Deep Sea Drilling Project (DSDP) and ODP. Perhaps the best example is Hole 504B, which now penetrates $2111 \mathrm{~m}$ into 6-m.y.-old crust in the southern flank of the Costa Rica Rift (Fig. 1), far deeper into oceanic crust than any other DSDP/ ODP hole. Several packer experiments conducted at various stages of the drilling history of Hole 504B have produced our most complete description of the depth-variation of permeability at an ocean crustal site (Fig. 2), even if it is still inadequate in detail. The permeability profile from Hole 504B has been used quite successfully to model off-axis circulation and simulate the variation of surface heat flow at the Costa Rica Rift (e.g., Fisher et al., 1990, 1994; Fisher and Becker, 1995). In addition, the correspondence between permeability and sonic velocity profiles in Hole 504B has been used to infer a permeability structure for modeling other ridge flank hydrothermal systems where there is good seismic control.

The primary goal of Leg 148 was to core even deeper in Hole 504B and then to conduct a full set of downhole experiments including further permeability measurements. In particular, the planned program was to have included a new packer/injection/flowmeter experiment designed to assess the fine-scale distribution of permeability in the upper part of basement in Hole 504B (Morin et al., 1988; Becker et al., 1994). Unfortunately, the drilling difficulties encoun-

\footnotetext{
'Alt, J.C., Kinoshita, H., Stokking, L.B., and Michael, P.J. (Eds.), 1996. Proc. ODP, Sci. Results, 148: College Station, TX (Ocean Drilling Program).

${ }^{2}$ Division of Marine Geology and Geophysics, Rosenstiel School of Marine and Atmospheric Science, 4600 Rickenbacker Causeway, University of Miami, Miami, FL
} 33149, U.S.A. Kbecker@ismas.miami.edu tered in Hole 504B and resultant operational considerations precluded the planned permeability experiments. Nevertheless, the subsequent drilling success less than $1 \mathrm{~km}$ away at Hole 896A (Fig. 3) presented an exciting opportunity to assess the permeability structure in that hole. This paper presents the results of the permeability measurements made during Leg 148 in Hole 896A, and then focuses on a comparison of those results with the previous measurements in Hole 504B and the implications of this comparison for the lateral variability of permeability in the young oceanic crust south of the Costa Rica Rift.

\section{METHODS AND ASSUMPTIONS}

The packer experiments in Hole 896A were conducted using a resettable drill-string packer manufactured by TAM International and described by Becker $(1986,1988)$. This packer incorporates inflatable rubber elements to isolate a section of the hole, and can be configured as a single or a straddle packer. For the measurements in Hole $896 \mathrm{~A}$, it was deployed with a single element (Fig. 4) and inflated once in the casing and twice in the open-hole section to isolate three overlapping zones between the packer and the bottom of the hole at 469 mbsf. The same packer had previously been used to measure the permeability of the deeper sheeted dike section in Hole 504B (Becker, 1989), and a more complex inflatable drill-string packer made by Lynes International had been used during DSDP investigations to assess the permeability of the extrusive rocks and upper sheeted dikes in Hole 504B (Anderson and Zoback, 1982; Anderson et al., 1985).

All of the packer experiments conducted to date in Holes 504B and $896 \mathrm{~A}$ have been standard slug or injection tests (described in more detail below), in which the transmissivities and average formation permeabilities of the zones isolated between the packer and the current bottom of the hole have been determined. When used in this fashion, the TAM packer is actuated using a "go-devil" that is dropped down the drill string into the packer inflation subassembly. The go-devil also carries recorders to monitor downhole fluid pressures in the isolated, pressurized zone during the experiment; these pressures are the primary data from which formation transmissivity and permeability are calculated. When more than one packer inflation is attempted, as during Leg 148, the go-devil may be either re- 


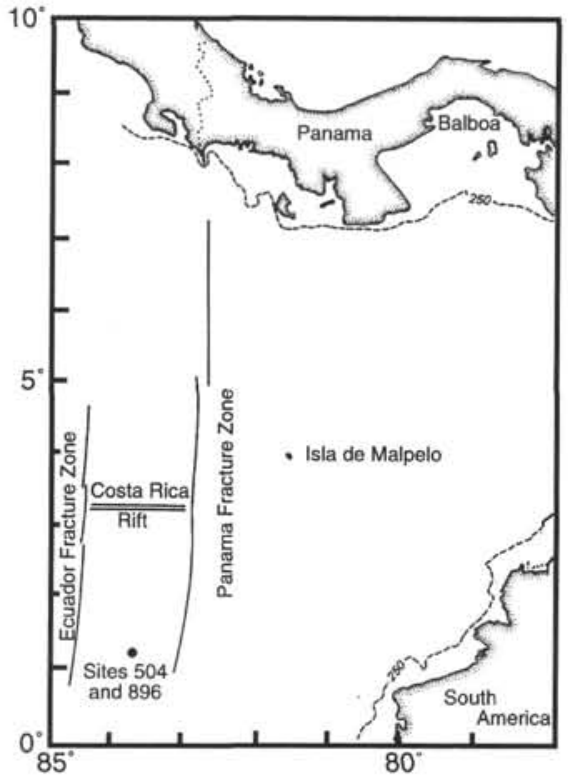

Figure 1. Location of Sites 504 and 896 on the south flank of the Costa Rica Rift.

trieved and redressed or left in place when the packer is repositioned between inflations.

During Leg 148, the go-devils carried dual electronic "ERPG300 " gauges made by Geophysical Research Corporation (GRC). The ERPG-300 gauges record in electronic memory 10,000 digital pressure and temperature values sampled at 10.8 -s intervals over one day. The data from these gauges were not available until the go-devil was retrieved upon completion of the experiments. However, the entire drill string as well as the isolated zone was pressurized during testing, and a 5000-psi (34.5-MPa) Gould pressure transducer at the rig floor was continuously logged to provide a real-time record of downhole events. Throughout the packer measurements, pumping rates and pumped volumes were also logged at the rig floor by monitoring the strokes of the mud pump. Pumping rates were recorded in units of strokes per minute (spm), with one stroke of the mud pump volumetrically equivalent to $19.7 \mathrm{~L}$ of seawater, corrected for a pump efficiency of $95 \%$.

Once the packer was inflated in Hole 896A, two kinds of experiments were used to determine the permeability of the isolated interval: pressure pulse or "slug" tests and constant-rate injection tests. The methods used during Leg 148 were similar to those described by Anderson and Zoback (1982), Hickman et al. (1984), Anderson et al. (1985), and Becker $(1989,1990,1991)$ in conducting previous packer experiments in Holes 395A, 504B, and 735B. The procedures required for inflation of the packer always resulted in an initial slug test when the packer was locked in the inflated position. Injection tests generally disturb the pressure field in the formation around the hole much more than slug tests, and were therefore conducted after the slug tests at appropriate inflation depths. When a sequence of tests was conducted at a single inflation depth, the data from each test were corrected for the extrapolated decay(s) of the previous test(s).

\section{Slug Test Procedures}

The slug tests were conducted following the methods for the "modified" slug test of Bredehoeft and Papadopulos (1980), which is an adaptation of the slug test method of Cooper et al. (1967) and Papadopulos et al. (1973) for formations with relatively low permeabilities. In the modified slug test, a short pressure pulse is applied to the fluid in the zone isolated by the packer, and the decay of this pulse is monitored as fluid flows from the pressurized borehole into the iso-

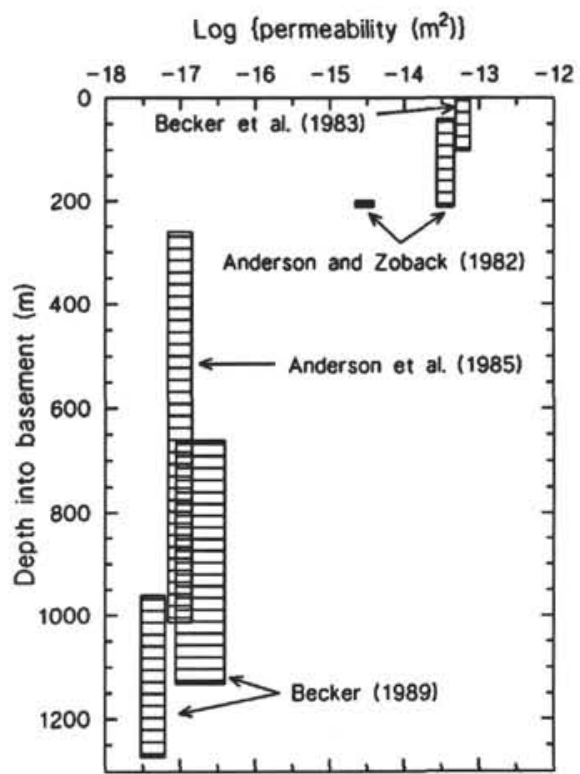

Figure 2. Permeabilities previously reported in Hole 504B vs. depth into basement. The vertical extent of each rectangle represents the vertical interval over which the average permeability was measured; the horizontal extent represents the estimated error range in the permeability value.

lated formation. The decay of such a pressure pulse is described by the equation

$$
P(t) / P_{0}=F(\alpha, \beta),
$$

where $P$ is pressure in excess of the initial undisturbed value, $P_{0}$ is the initial pressure increase, $\alpha$ is a dimensionless parameter that depends on the storage coefficient $(S)$ and porosity $(\phi)$ of the isolated formation, $B$ is a dimensionless parameter that depends on the transmissivity $(T)$ and permeability $(k)$ of the formation, and $F$ is a complicated infinite integral. More specifically,

$$
\begin{gathered}
\alpha=\pi a^{2} S / V_{w} C_{w} \rho_{w} g, \\
B=\pi T t / V_{w} C_{w} \rho_{w} g, \\
S=b \phi C_{i} \rho_{i} g,
\end{gathered}
$$

and

$$
T=b k \rho_{i} g / \mu,
$$

where $t$ is time, $g$ is gravitational acceleration, $a$ is the radius of the hole in the isolated zone, $b$ is the height of the isolated zone, $C_{i}, \rho_{i}$, and $\mu$ are, respectively, the compressibility, density, and dynamic viscosity of the fluid in the isolated zone, and $C_{w}$ and $\rho_{w}$ are the compressibility and density of the fluid in the total pressurized volume $V_{w-}$ (Note that the total pressurized volume $V_{w}$ includes the rig floor plumbing and drill string in addition to the zone isolated below the packer.)

To process the pressure data measured during slug tests, we followed the standard curve-fitting method described by Cooper et al. (1967) and Papadopulos et al. (1973). A plot of the decay of measured pressures vs. $\log$ time was superposed on a family of type curves of $F(\alpha, \beta)$ vs. $\log \beta$ calculated for various values of $\alpha$ spanning several orders of magnitude. The data plot was then shifted along the abscissa of the type-curve plot to visually determine the value of $\alpha$ for which the data best fit the type curve. Then the transmissivity and average permeability of the tested interval could be calculated from 


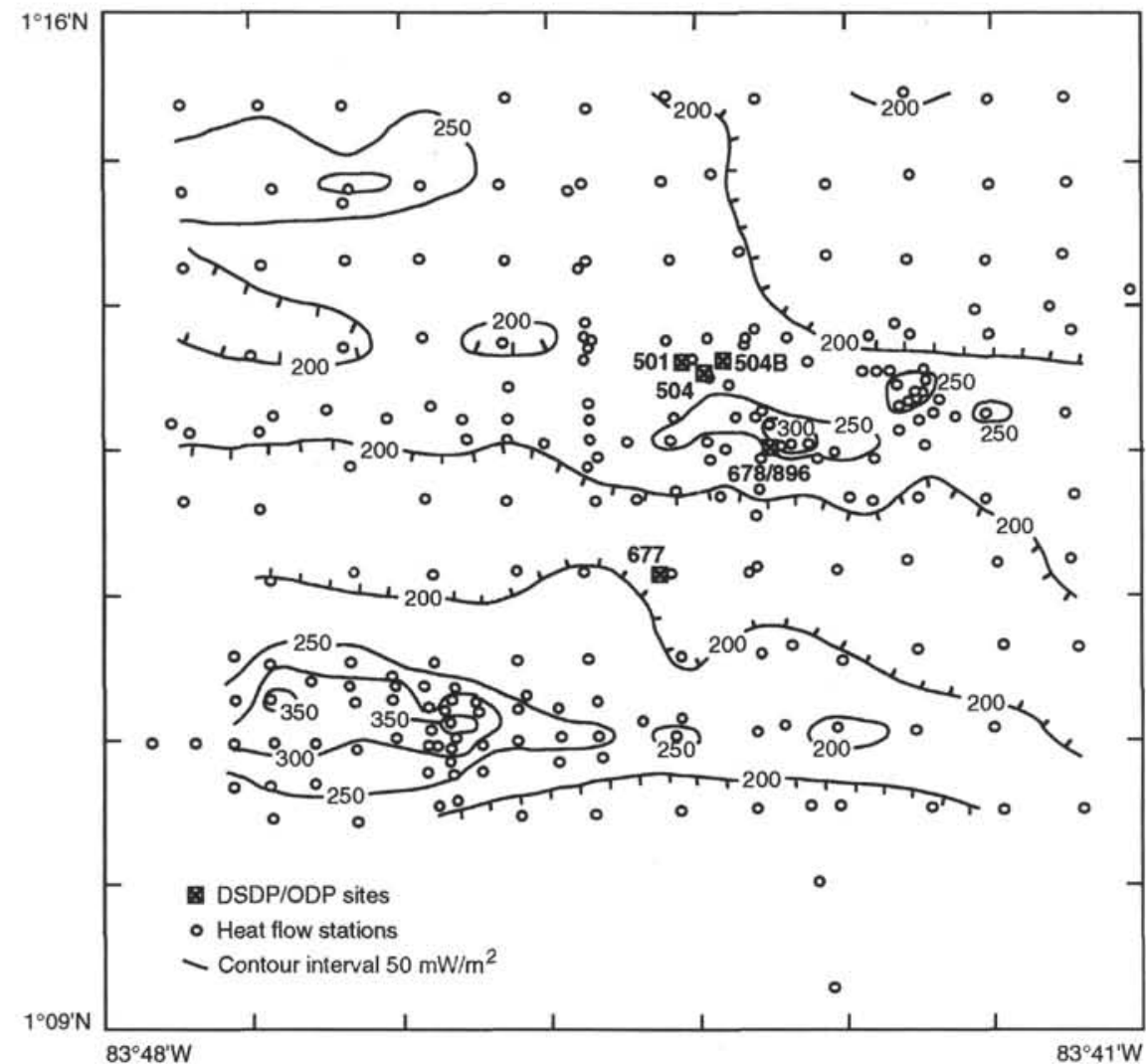

Figure 3. Locations of Sites 501, 504, 677, 678, and 896 plotted with the detailed heat-flow data from the surrounding $10 \times 10 \mathrm{~km}$ region (Langseth et al., 1988).

the correspondence between the values of time and $B$ for the best-fit curve, using the definitions for $B$ and transmissivity given in Equations 3 and 5 .

As noted by Cooper et al. (1967), Papadopulos et al. (1973), Bredehoeft and Papadopulos (1980), and Hickman et al. (1984), the calculated type curves are relatively insensitive to changes in $\alpha$ and much more sensitive to changes in $B$. Thus, this procedure yields relatively poor estimates of the storage coefficient and porosity, but reasonable determinations of transmissivity and average permeability. Even where there are differences between borehole hydrostatic pressures and formation pressures, as occurred in the upper part of Hole 504B and possibly in Hole 896A, Coyle and Zoback (1988) showed that (1) the early slug test data reliably determine the proper type curve and (2) the later slug test data are sensitive to the proper choice of a reference pressure.

\section{Constant-rate Injection Tests}

In a relatively permeable formation, a slug test will decay quite rapidly, and a better determination of permeability can be obtained by conducting a constant-rate injection test. In this experiment, the borehole pressure within the isolated zone is monitored as fluids are pumped into the formation at a constant rate. As long as injection rates are kept sufficiently low as to not hydrofracture the formation, the rise of pressure as injection proceeds quickly becomes linear with the log of time, according to the following equation (Horner, 1951; Matthews and Russell, 1967):

$$
P\left(t_{i}\right)=(q \mu / 4 \pi k b) \ln \left(\gamma \phi \mu C_{i} a^{2} / 4 k t\right),
$$

where $P$ is the pressure increase over the in situ formation pressure, $t_{i}$ is time since the start of injection, $q$ is the constant flux of injected fluids, $\gamma$ is Euler's constant, and the remaining parameters are defined previously. When the injection is stopped, and if the hole is "shut in" such that pressures are not vented at the rig floor, then pressures will decay toward in situ pressures according to the classic Horner equation:

$$
P\left(t_{s}\right)=(-q \mu / 4 \pi k b) \ln \left(t_{i} / t_{s}\right),
$$

where $t_{s}$ is time since the end of injection and beginning of shut in and $t_{i}$ remains the time since the beginning of injection.

Thus, the average permeability of the isolated zone can be determined in two manners from an injection test: (1) directly from the slope of the linear section of a plot of pressure vs. In time during injection at a measured constant rate and (2) from the slope of the linear section of a similar plot of the decay of pressures vs. In $\left(t_{i} / t_{s}\right)$ in the shut-in hole after injection is stopped. These should yield similar results; if not, it may be an indication that during injection the pressurized fluids either leaked past the packer seal or opened preexisting cracks in the formation to effectively increase permeability. If pressures during injection quickly reach a nearly steady-state value, then permeability may also be estimated using Glover's formula (Snow, 1968), which results from a steady-state approximation to the injection Equation 6:

$$
k=(q \mu / 2 \pi b \Delta P) \ln (b / a),
$$

where $\Delta P$ is the nearly steady-state pressure increase and the remaining parameters are as defined previously.

\section{In Situ Permeability vs. Calculated Bulk Permeability}

Both slug and injection tests involve an important assumptionthat the permeability of the rock in the zone isolated by the packer 


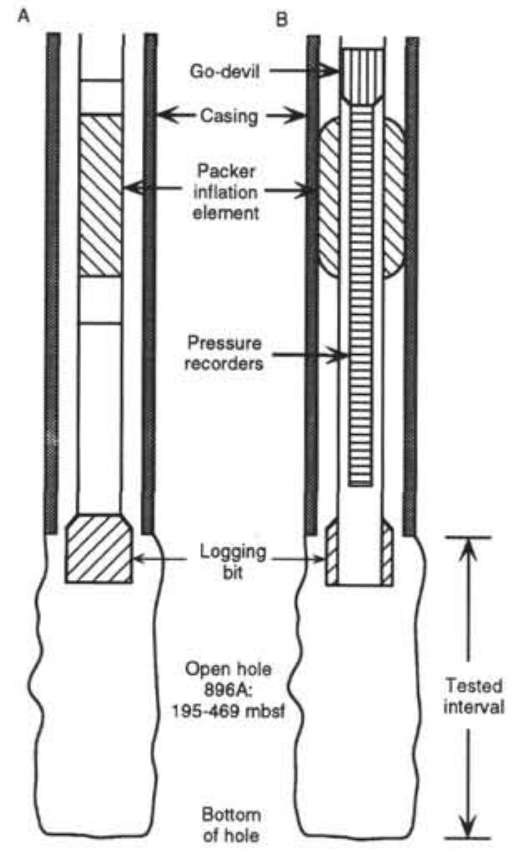

Figure 4. Sketch of the ODP inflatable drill-string packer, as used during Leg 148 for the first inflation in casing in Hole 896A. A. The packer incorporated in the bottom-hole assembly, before inflation or after deflation. B. Cut-away sketch of the inflated packers showing go-devil, pressure recorders, and tested interval between the casing shoe and the bottom of the hole. During inflation of the packer, the go-devil directs fluids pumped from the rig floor into the inflation elements; once the packer is inflated, the go-devil position is shifted such that fluids pumped from the rig floor are directed into the tested interval.

is homogeneous and isotropic throughout the test zone. The homogeneity assumption is probably not strictly valid for the upper crust in Holes $896 \mathrm{~A}$ or $504 \mathrm{~B}$, where logging data and numerical modeling suggest that some of the transmissivity may be dominated by discrete zones with high hydraulic conductivity (e.g., Pezard et al., 1992; Fisher et al., 1994; Pezard et al., this volume). Nevertheless, this assumption probably "becomes more valid as the scale of the permeability tests (i.e., the length of the zone isolated by the packer) increases with respect to the spacing of the fractures" (Hickman et al., 1984; Parsons, 1966). The permeabilities computed here are average Darcian or equivalent porous-medium permeabilities, denoted as bulk permeabilities, obtained by applying the theory for uniformly permeable media. If the actual permeability structure is indeed dominated by isolated fractures, the hydraulic conductivities of such fractures may be significantly greater than the values reported here.

\section{Properties of the Fluids in the Pressurized System}

The transient pressures measured during both slug and injection tests depend on the properties of the pressurized fluids, particularly viscosity and compressibility, which vary with both temperature and pressure. For the temperature-dependent viscosity of seawater, two relationships were used: (1) for temperatures less than $25^{\circ} \mathrm{C}$, interpolation among oceanographic values given by Sverdrup et al. (1942, p. 69), and (2) for temperatures greater than $25^{\circ} \mathrm{C}$, Gartling's (1977) empirical equation, $\mu\left(10^{-3} \mathrm{~Pa}-\mathrm{s}\right)=16.68 T^{-0.8987}$, with $T$ in ${ }^{\circ} \mathrm{C}$. Actual temperatures in the zones pressurized during the packer experiments ranged from bottom-water values to formation values, and appropriate average values for the pressurized intervals had to be estimated. These values were estimated using the sensors in the GRC recorders,
Table 1. Summary of the calculations of transmissivity $(T)$ and average permeability $(k)$ for the packer experiments conducted in Hole 896A.

\begin{tabular}{|c|c|c|c|c|c|c|}
\hline Test & a & $\begin{array}{l}t_{1}^{*} \\
\text { (s) }\end{array}$ & $\begin{array}{c}C^{* *} \\
\left(10^{-9} \mathrm{~Pa}^{-1}\right)\end{array}$ & $\begin{array}{c}\text { Injection rate } \\
(\mathrm{L} / \mathrm{s})\end{array}$ & $\begin{array}{c}T \\
\left(10^{-5} \mathrm{~m}^{2} / \mathrm{s}\right)\end{array}$ & $\left(10^{-14} \mathrm{~m}^{2}\right)$ \\
\hline \multicolumn{7}{|c|}{ Packer in casing, $V_{w}=52.1 \mathrm{~m}^{3}$, average temperature $\approx 5^{\circ} \mathrm{C}, \mu=0.00161 \mathrm{~Pa}-\mathrm{s}$ : } \\
\hline Slug \#1 & 0.001 & 32.3 & $(52.5)$ & - & 27.6 & 15.7 \\
\hline Slug \#2 & 0.001 & 24.5 & 46.1 & - & 31.9 & 18.2 \\
\hline Injection \#1 & - & - & - & 4.6 & 9.01 & 5.13 \\
\hline Shut in \#1 & - & - & - & - & 9.89 & 5.63 \\
\hline Injection \#2 & - & - & - & 10.2 & 21.7 & 12.3 \\
\hline Shut in \#2 & - & - & - & - & 16.9 & 9.63 \\
\hline \multicolumn{7}{|c|}{ Packer at $233 \mathrm{mbsf}, V_{w}=45.4 \mathrm{~m}^{3}$, average temperature $\approx 10^{\circ} \mathrm{C}, \mu=0.00139 \mathrm{~Pa}-\mathrm{s}:$} \\
\hline Slug \#3 & 0.3 & 57.5 & (7.82) & - & 2.01 & 1.16 \\
\hline Slug \#4 & 0.1 & 45.7 & 12.8 & - & 4.14 & 2.38 \\
\hline Injection \# $3 \mathrm{a}^{\dagger}$ & - & - & - & 2.7 & 2.64 & 1.52 \\
\hline Injection $\# 3 \mathrm{~b}^{\dagger}$ & - & - & - & 4.3 & 1.89 & 1.08 \\
\hline Shut in $\# 3$ & - & - & - & - & 1.75 & 1.01 \\
\hline \multicolumn{7}{|c|}{ Packer at 385 mbsf, $V_{w}=37.4 \mathrm{~m}^{3}$, average temperature $\approx 20^{\circ} \mathrm{C}, \mu=0.00109 \mathrm{~Pa}-\mathrm{s}:$} \\
\hline Slug \#5 & 0.001 & 32.4 & (2.11) & - & 0.796 & 1.01 \\
\hline Slug \#6 & 0.001 & 34.7 & 2.52 & - & 0.888 & 1.12 \\
\hline Slug \#7 & 0.001 & 37.2 & 2.95 & - & 0.968 & 1.23 \\
\hline Slug \#8 & 0.001 & 37.2 & 2.61 & - & 0.856 & 1.08 \\
\hline
\end{tabular}

*For a slug test, the parameter $t_{/}$corresponds to the amount (in seconds) that the type curve was shifted to produce the best fit to the data; $T$ and $k$ are calculated from $t_{l}$ by the equations $T=V_{w} C_{w^{r}} g / \pi t_{1}$ and $k=\mu V_{w} C_{w} / \pi b t_{1}$.

*** Effective compressibilities calculated from volumes pumped and pressure rises observed downhole during slug tests. As explained in the text, this was not possible for the first slug test (shown in parentheses) at each packer inflation; instead, the compressibility values shown in parentheses were assumed using the volume pumped for the next slug test.

$\doteqdot$ As explained in the text, injection tests \#3a and \#3b are the two segments of the first injection test, during which the injection rate was started at $8.1 \mathrm{spm}$ but inadvertently increased to $13.1 \mathrm{spm}$ after about $5 \mathrm{~min}$.

which generally indicated that the greater proportions of the isolated sections were kept quite close to ocean bottom-water temperatures.

As noted by Neuzil (1982), the effective compressibility of the fluid in a shut-in hole is sometimes greater by up to 1 order of magnitude than that of the pure fluid (seawater in this case) because of (1) compliance of the drill string and test equipment and (2) air possibly trapped in the system. Note that no accumulator is used with the mud pump, so the pump itself is probably not a significant source of system compliance. While every effort was made during Leg 148 to purge all air from the packer, drill string, pump, and connecting plumbing, small amounts of air may have remained in the system. Such trapped air would have increased the effective system compressibility and caused the transmissivity and bulk permeability calculated in a slug test to be erroneously low if the pure fluid compressibility value were used. Therefore, we carefully recorded the volumes pumped downhole during slug tests, so that the effective compressibility of the pressurized system could be determined using the definition of compressibility, $C=\mathrm{d} V / V \mathrm{~d} P$, and then be used in the calculation of formation permeability. This was not possible for the initial slug test that occurred automatically on packer inflation, as it was impossible to distinguish what proportion of the pumped fluids went into the packer elements as opposed to being applied to the isolated zone as a pressure pulse. The results (Table 1) were consistent with the experience of Neuzil (1982), with calculated compressibilities being greater than the value for pure seawater.

Similarly, in interpreting the slug tests conducted deep in Hole 504B, Becker (1989) calculated effective compressibilities and then used them to calculate transmissivities and permeabilities. However, this procedure was not followed in the earlier DSDP packer work in the upper part of Hole 504B; instead, Anderson and Zoback (1982) and Anderson et al. (1985) used the tabulated compressibility for pure seawater. As will be discussed further in the following, this difference in procedures must be kept in mind when comparing the results from different depths in Hole 504B and when comparing results from Holes 504B and 896A. 


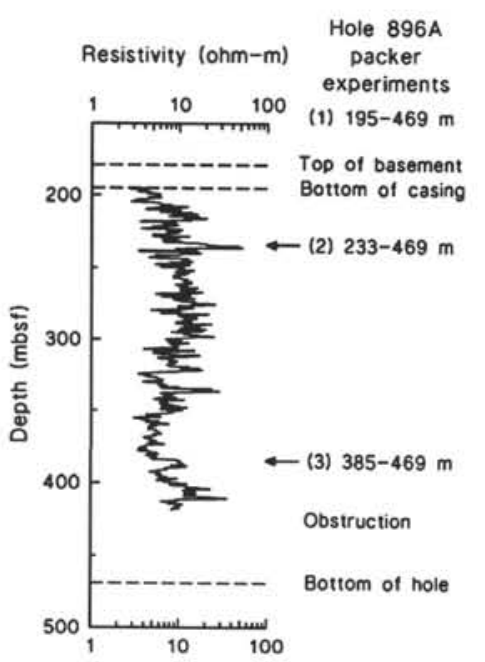

Figure 5. Summary of the sequence of packer measurements conducted in Hole $896 \mathrm{~A}$, along with the deep-penetrating resistivity log recorded with the Schlumberger Dual Laterolog. In the column on the right, the numbers in parentheses (1-3) denote the sequence of packer inflations at the depths indicated by the arrows, with the depth ranges denoting the intervals over which the respective experiments were conducted. For the first experiment, the packer was inflated at $106 \mathrm{mbsf}$ within casing, but the top of the tested interval is assumed to be the bottom of the casing at 195 mbsf.

\section{EXPERIMENTAL RESULTS IN HOLE 896A}

The packer experiments in Hole 896A were conducted after the hole had been cased to $195.1 \mathrm{mbsf}$ and then cored to $469 \mathrm{mbsf}$. The top of basement was determined in exploratory drilling to be at 179 mbsf, so Hole 896A extends $290 \mathrm{~m}$ into basement and the open-hole interval tested during the packer experiments encompasses $16-290 \mathrm{~m}$ into basement. The cored section consisted of a sequence of pillow and flow basalts generally similar to those cored in the upper part of Hole 504B (Alt, Kinoshita, Stokking, et al., 1993), except for an indication of more extensive sealing by alteration products in the recovered core.

The packer experiments were conducted early in the logging program at Hole $896 \mathrm{~A}$, and the packer setting positions were selected on the basis of a resistivity $\log$ and a caliper log that was later shown to be inaccurate. The caliper log gave erroneously large readings of hole size and falsely indicated that there were only a few depths at which hole diameters would allow the packer to be safely inflated, although the Formation MicroScanner log conducted after the packer work indicated that the packer could have been inflated nearly anywhere in the hole. Based partly on the misleading caliper information, three inflation points were selected, first in casing, and then in resistive zones with apparently acceptable diameters at 233 and 385 mbsf (Fig. 5). The downhole pressure and temperature records for all three inflations are shown in Figure 6. Note that the go-devil was not retrieved between the first two inflations, so that Figures $6 \mathrm{~A}$ and $6 \mathrm{~B}$ compose a continuous 8-hr record, but it was retrieved, redressed, and redeployed for the third packer inflation.

\section{Inflation in Casing at 106 mbsf}

The packer was first inflated at $106 \mathrm{mbsf}, 89 \mathrm{~m}$ above the bottom of the casing, effectively testing the permeability of the entire openhole interval 195-469 mbsf. Had the results from this initial packer inflation indicated that the formation was relatively impermeable, the packer experiments would have been terminated and the limited time remaining in the leg devoted to other logs. However, the initial infla-
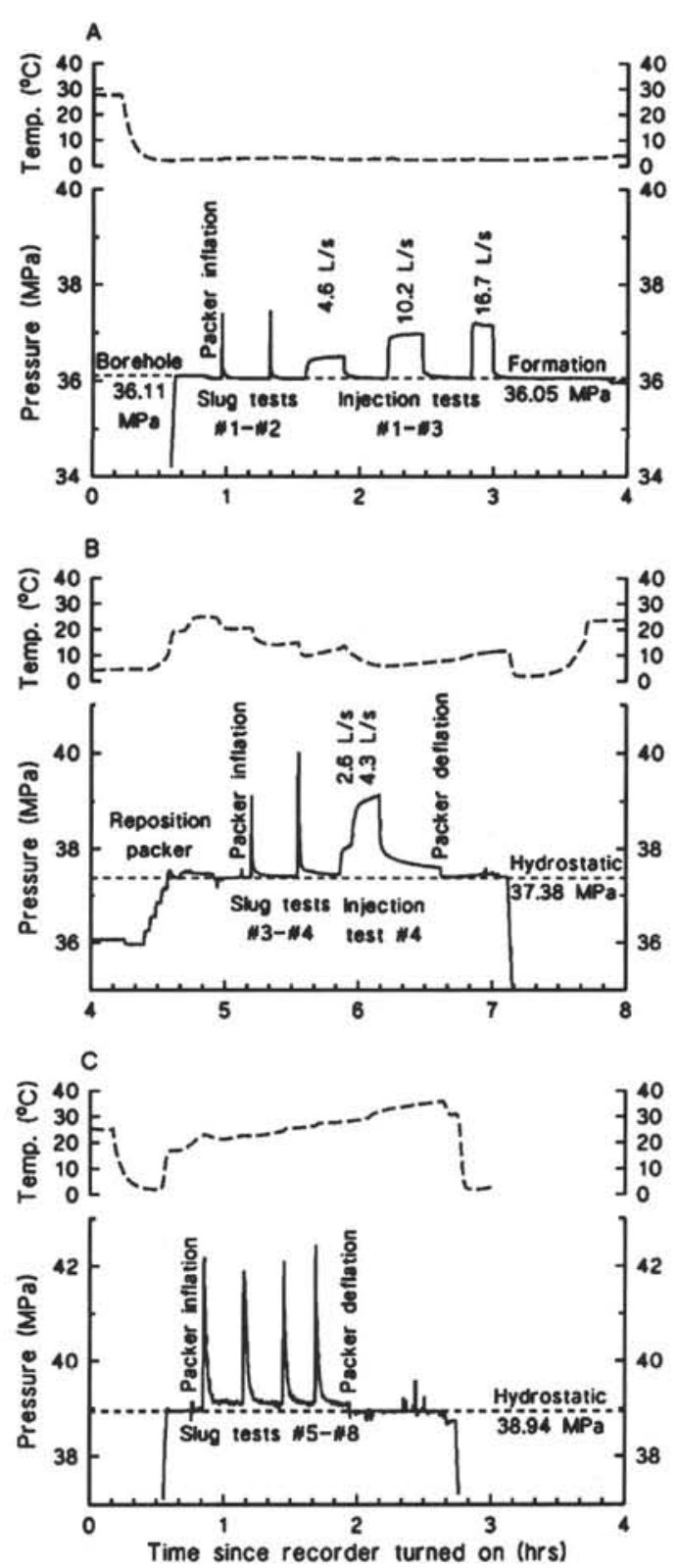

Figure 6. Annotated pressure-time records and gauge temperatures collected downhole during the packer experiments conducted in Hole 896A. A. Packer inflated in casing at 106 mbsf. B. Packer inflated in open hole at $233 \mathrm{mbsf}$. C. Packer inflated in open hole at $385 \mathrm{mbsf}$. Note that all three plots are scaled so the axes span comparable ranges. Note also that Figures $6 \mathrm{~A}$ and $6 \mathrm{~B}$ form a continuous record, in which the changes in the pressures recorded from 3:50 to $4: 55$ result from pipe-running operations to move the packer to 233 mbsf.

tion indicated significant transmissivity, and the subsequent inflations were carried out to assess the depth dependence of the transmissivity and permeability of the formation.

As with all packer inflations in casing, the interpretation of the results of the first inflation rest on the assumption that the casing is adequately cemented into place, so that the hydrologic properties of the formation were actually assessed. Although there was no cement bond log conducted to assess the quality of the cement job, some evidence for the hydraulic integrity of the cement was provided by the background pressures recorded immediately before and after the 

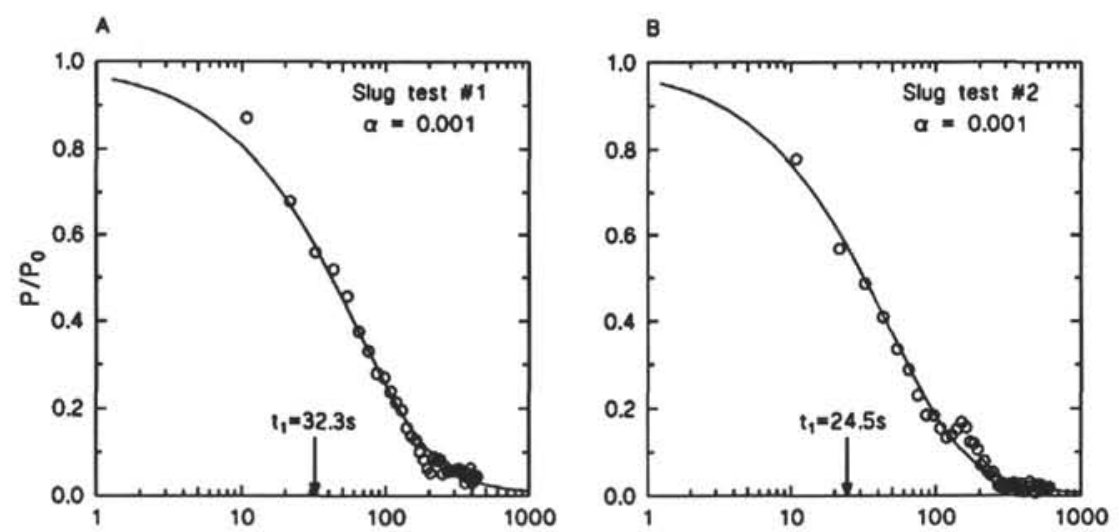

C

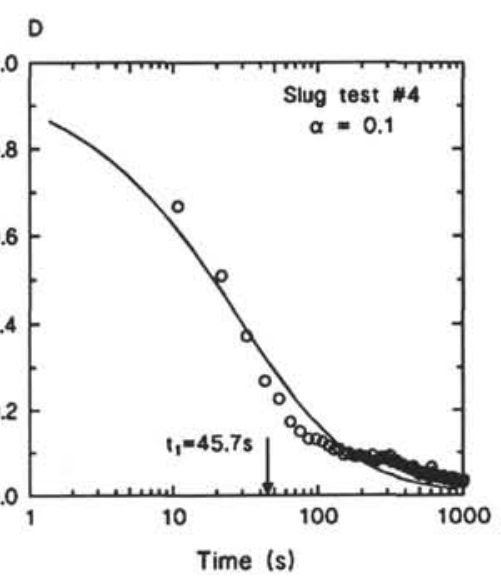

Figure 7. Best fits of measured data (circles) to the type curves of Cooper et al. (1967) of the pressures recorded during slug tests \#1 and \#2 (A and B) conducted with the packer inflated in casing and slug tests \#3 and \#4 (C and D) conducted with the packer inflated in open hole at 233 mbsf. The arrows denote the amount $t_{l}$ by which the type curve was shifted for the best match to the data; transmissivity and permeability are calculated from $t_{l}$.

packer inflation (at about $0.7-0.9 \mathrm{hr}$ on Fig. 6A). Before the packer was inflated, the pressure gauges in the go-devil registered a coldborehole hydrostatic pressure; as the packer was inflated, the gauges showed a shift of about $-0.06 \mathrm{MPa}$, indicating a differential pressure between cold hydrostatic pressure in the borehole and warm hydrostatic formation fluid pressure. This shift was then reversed on deflation (at about $4 \mathrm{hr}$ at the transition between Figs. 6A and 6B). The sense of the differential is consistent with the density difference between the cool drilling fluids and the warm formation fluids, but the magnitude is considerably less than the maximum possible if the borehole fluids were isothermal at the bottom-water value. Nevertheless, such a differential could not have been maintained over the packer inflation period if the cement behind the casing did not have good hydraulic integrity.

As shown in Figure 6A, two slug tests and three injection tests were attempted with the packer inflated in casing. Pressures measured during the two slug tests and the first two injection tests behaved according to theory and are analyzed herein by the methods described above. However, pressures in the last injection test, at the highest injection rate, do not behave properly, possibly because of leakage past the packer, and are not suitable for determination of permeability. The slug test data fit the type curves quite well (Figs. 7A, $\mathrm{B})$, and the data from the first two injection and shut-in tests show the prescribed approach to a linear relationship with In time (Figs. 8A, B). These data yield six independent determinations of transmissivity and bulk permeability for the entire open-hole interval (Table 1). However, there is an unacceptable spread among these values, and the most reliable results are probably those from the first injection test, for the following reasons:

The slug test data are probably the least reliable, in that unusually large pumped volumes were required to produce the pressure pulses (about 3 times the volumes needed for the other slug tests conducted at the other inflation depths), resulting in significantly larger values for the calculated compressibilities. It is possible that this could have resulted from leakage past the packer, but it should be noted that similar effects have been observed in conducting slug tests in zones with apparently high transmissivities in Holes 395A and 735B (Becker, 1990 and 1991, respectively). This suggests that, when conducting slug tests with the ODP equipment in highly transmissive formations, a significant proportion of the fluid pumped for a pressure pulse may be lost into the formation during the attempt to produce the pressure pulse itself. Such an effect would certainly produce significantly larger uncertainties in the effective compressibilities and the resultant transmissivity and permeability values derived from the slug tests. Although it may be coincidence, it is suspicious that the transmissivities calculated from the slug tests are about 3 times greater than the preferred value derived from the lower rate injection test, just as it required about 3 times as much fluid pumped to produce the slug tests.

The results of the two injection tests are more consistent, but the higher injection rate produced a higher apparent transmissivity. This suggests an effective pressure dependency, such that the more reliable injection test was that conducted at the lower rate. In addition, the results from the injection and shut-in phases of this first test are quite consistent (Table 1). Thus, the values from the first injection 

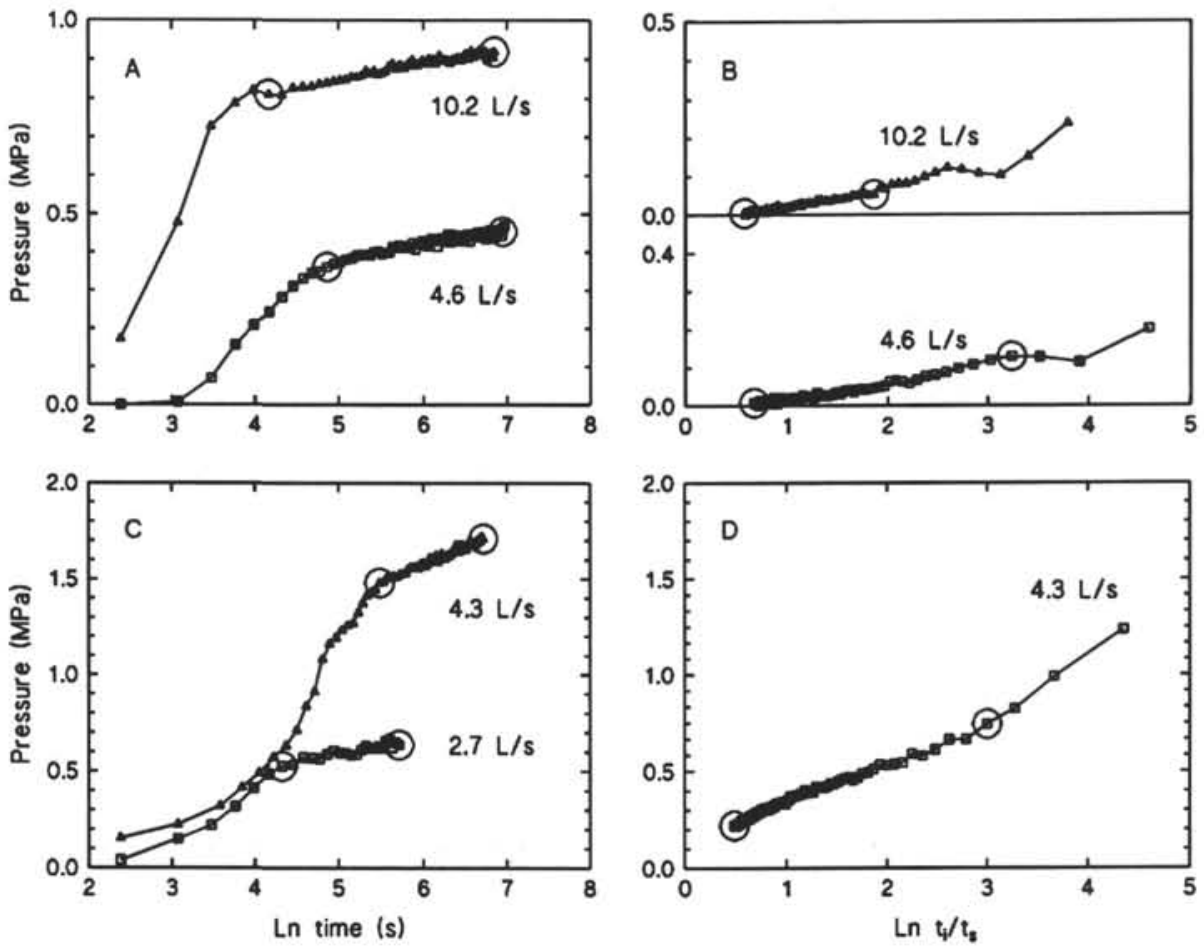

Figure 8. Results of processing the three two-injection tests conducted in Hole 896A. A. Rise of corrected pressures during injection vs. the log of time since injection was started, for injection tests \#1 and \#2 conducted with the packer inflated in casing. B. Decay of corrected pressures in the shut-in hole after injection was ended for the same two injection tests. C. Rise of corrected pressures during injection vs. the log of time since injection was started, for injection test \#3 conducted with the packer inflated in open hole at $233 \mathrm{mbsf}$. D. Decay of corrected pressures in the shut-in hole after injection was ended, for injection test \#3. In all plots, the circles denote the end points of the linear segments of these curves; slopes of these linear segments were obtained by linear regression and used in the calculation of the transmissivities and permeabilities reported in Table 1.

test are taken herein to be the most representative of the bulk transmissivity and permeability of the entire open-hole interval, respectively about $9 \times 10^{-5} \mathrm{~m}^{2} / \mathrm{s}$ and $5 \times 10^{-14} \mathrm{~m}^{2}$.

\section{Inflation in Open Hole at 233 mbsf}

The next inflation point was chosen as shallow in the open-hole interval as seemed possible, for two reasons: (1) to test as much of the open-hole section as possible with an inflation in open hole, in the unrealized event that the data from the first inflation were to indicate a hydraulic leak past the cement behind the casing, and (2) to assess the variation in permeability in the uppermost basement, where the strongest gradients in permeability were expected. The second inflation depth was chosen at 233 mbsf, in a resistive unit (Fig. 5) that appeared in the misleading caliper log as the shallowest open-hole formation with a diameter small enough for a good packer seat. With the packer inflated here, two slug tests (\#3 and \#4) were conducted, followed by injection test \#3 (Fig. 6B). During the injection test, the low initial rate of injection could not be maintained accurately and was inadvertently increased after about $5 \mathrm{~min}$ of injection, resulting in a shoulder on the pressure rise (Fig. 6B). The data were interpreted as two separate injection tests, \#3a and \#3b, with the pressures from \#3b first requiring a correction for the residual effect of injection during \#3a.

The slug tests conducted with the packer at 233 mbsf required longer decay periods than had been observed during the first two slug tests with the packer in casing, and the injection test produced a quicker pressure increase at a lower injection rate than during the injection tests with the packer in casing. These are both indications of a significant reduction of transmissivity and permeability below 233 mbsf, given the small difference in the lengths of the two test intervals. Indeed, the type curve fits for the slug tests (Figs. 7C, D) and the semi-log plots for the injection and shut-in tests (Figs. 8C, D) result in calculated transmissivities and permeabilities approaching 1 order of magnitude less than the values calculated for the entire open-hole interval (Table 1). Over the five separate tests, the average transmissivity and permeability for the interval $233-469 \mathrm{mbsf}$ are $2.5 \times 10^{-5}$ $\mathrm{m}^{2} / \mathrm{s}$ and $1.4 \times 10^{-14} \mathrm{~m}^{2}$, respectively.

Given the difference in transmissivities between the first two largely overlapping test intervals (195-469 and 233-469 mbsf), it is likely that much of the transmissivity sensed in the first packer inflation resides above $233 \mathrm{mbsf}$. The apparent transmissivity of the interval 195-233 mbsf can be obtained directly as the difference in transmissivities determined for the two packer test intervals, or about $5 \times 10^{-5} \mathrm{~m}^{2} / \mathrm{s}$, with the uncertainties additive. This results in an apparent bulk permeability of about $2 \times 10^{-13} \mathrm{~m}^{2}$ for the interval $195-233$ mbsf, again based on the assumption of hydraulic integrity of the cement behind the casing.

\section{Inflation in Open Hole at 385 mbsf}

The last packer inflation was conducted fairly near the bottom of the hole, to further assess the variation of permeability with depth and specifically to test whether there was any evidence in Hole 896A of the sharp permeability reduction reported by Anderson et al. (1985) at similar depths in Hole 504B (Fig. 2). The packer was inflated at $385 \mathrm{mbsf}$, again in a resistive zone that was one of the few places in the hole that yielded reasonable hole diameters in the misleading caliper log. Four slug tests were conducted (\#5-\#8), with very consistent, moderately slow decay curves (Fig. 9). The data from these slug tests fit the type curves quite well and produced a narrow range of calculated transmissivities and permeabilities (Table 1). The consistent results yield average transmissivity and average permeability 


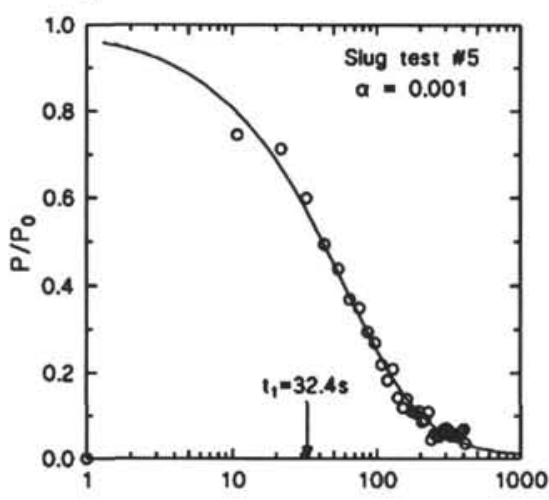

C

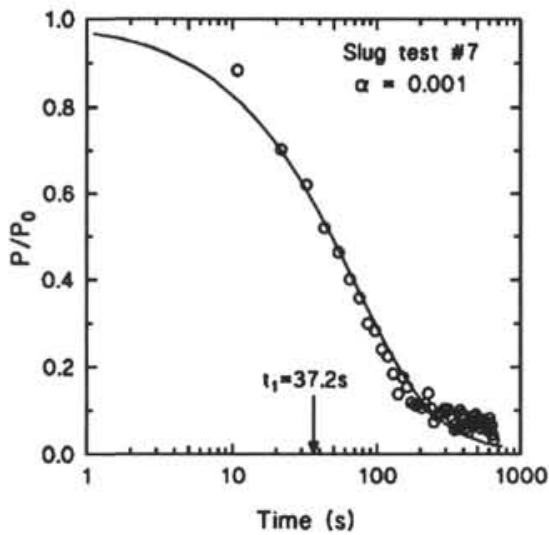

B

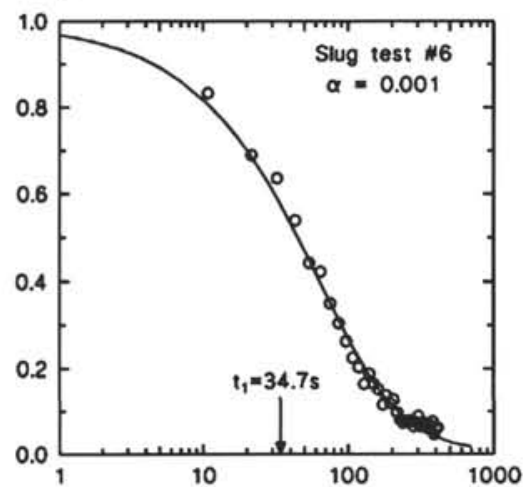

D

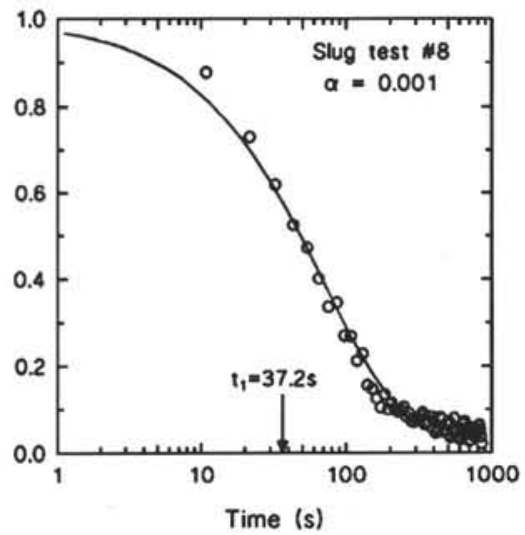

Figure 9. Best fits of measured data (circles) to the type curves of Cooper et al. (1967) of the pressures recorded during slug tests \#5-\#8 (A-D, respectively) conducted with the packer inflated in open hole at 385 mbsf. The arrows denote the amount $t$, by which the type curve was shifted for the best match to the data; transmissivity and permeability are calculated from $t_{l}$.

values for the interval $385-469 \mathrm{mbsf}$ of $8.8 \times 10^{-6} \mathrm{~m}^{2} / \mathrm{s}$ and $1.1 \times$ $10^{-14} \mathrm{~m}^{2}$, respectively. The latter is similar to the permeability value obtained for the larger interval $233-469$ mbsf; taking the difference in transmissivities results in a similar calculated average permeability of about $1.3 \times 10^{-14} \mathrm{~m}^{2}$ for the interval $233-385 \mathrm{mbsf}$.

\section{DISCUSSION AND CONCLUSIONS}

Figure 10A shows the permeability structure in Hole 896A determined from the packer measurements reported in this study. Below about $50 \mathrm{~m}$ into basement, most of the upper crustal section penetrated in Hole $896 \mathrm{~A}$ has a permeability of about $10^{-14} \mathrm{~m}^{2}$, which is probably sufficiently permeable to support passive off-axis hydrothermal circulation. The $38-\mathrm{m}$ section immediately below casing appears to be more permeable, by about 1 order of magnitude. This could be taken to support the inference that much of the transmissivity in the upper crustal section at the site may be focused in relatively thin zones, given the evidence described above for the assumption of hydraulic integrity of the cement behind the casing. Fisher et al. (1994) and Fisher and Becker (1995) have found that kind of focused permeability structure essential in simulating the variation of heat flow measured around Sites 504 and 896 (Fig. 3; Langseth et al., 1988).

The permeabilities in the uppermost basement below casing combined with the differential pressure recorded between the borehole hydrostatic pressure and formation pressure during the first packer inflation are sufficient to induce a downhole flow of cold ocean bottom water into the formation. Such downhole flow was deduced from temperature logs when Hole 504B was first drilled (Becker et al.,
1983), and apparently is common at other sedimented young crustal sites (e.g., Hyndman et al., 1976; Becker et al., 1984; Morin et al., 1992). When Hole 504B was first drilled, the analogous pressure differential determined during a packer experiment (Anderson and Zoback, 1982) was significantly greater than that reported herein for Hole 896A. Thus, the rate of downhole flow in Hole 896A should have been proportionately lower, and its effect less noticeable on the temperature profile. During Leg148, a temperature log was conducted in Hole 896A after a brief pause in the operations there for work in Hole 504B (Alt, Kinoshita, Stokking, et al., 1993). That temperature log yielded equivocal results; it displayed the characteristic concave upward profile for downhole flow, but the profile became linear very close to the base of the casing. As a result, it was not interpreted to indicate downhole flow, but the packer measurements reported herein suggest that downhole flow at a modest rate must indeed have been occurring at the time.

Figure 10B shows the permeabilities measured in Hole 896A plotted with all other values reported from upper crustal DSDP/ODP holes, including Hole 504B about $1 \mathrm{~km}$ to the northwest of Hole $896 \mathrm{~A}$. Clearly, the permeabilities measured in Hole 896A are quite comparable to those measured in the upper crustal section of Hole $504 \mathrm{~B}$, with typical bulk values on the order of $10^{-14}$ to $10^{-13} \mathrm{~m}^{2}$. The agreement of values from the upper sections of basement in the two holes generally supports the inference that the upper $200 \mathrm{~m}$ of basement near the site is permeable on a regional scale - an assumption that is inherent in most numerical simulations of off-axis circulation on the flank of the Costa Rica Rift (e.g., Fisher et al., 1990, 1994). The upper crustal values in Holes 504B and 896A are also quite consistent with the average permeabilities of representative upper base- 
A

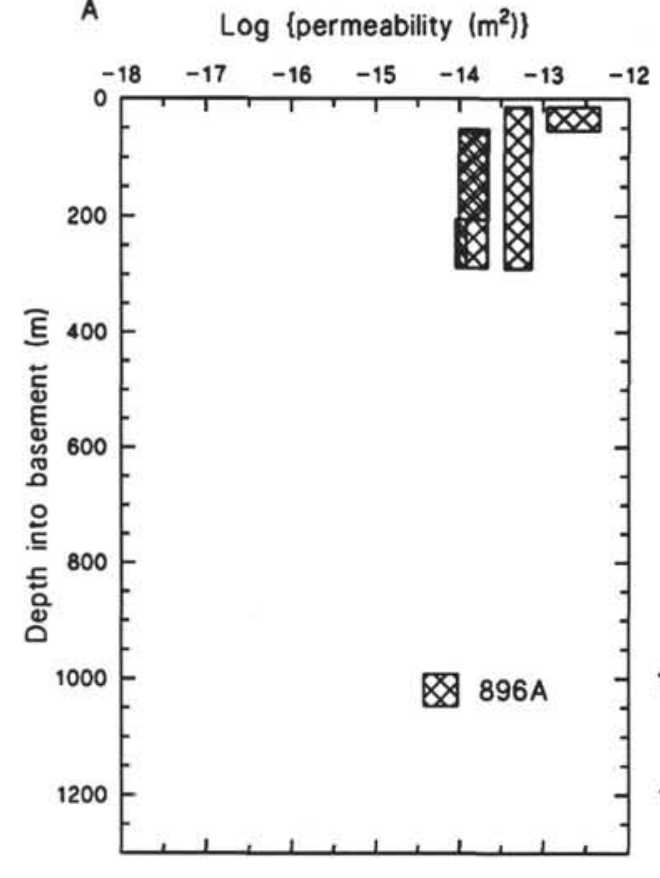

B $\log \left\{\right.$ permeability $\left.\left(\mathrm{m}^{2}\right)\right\}$

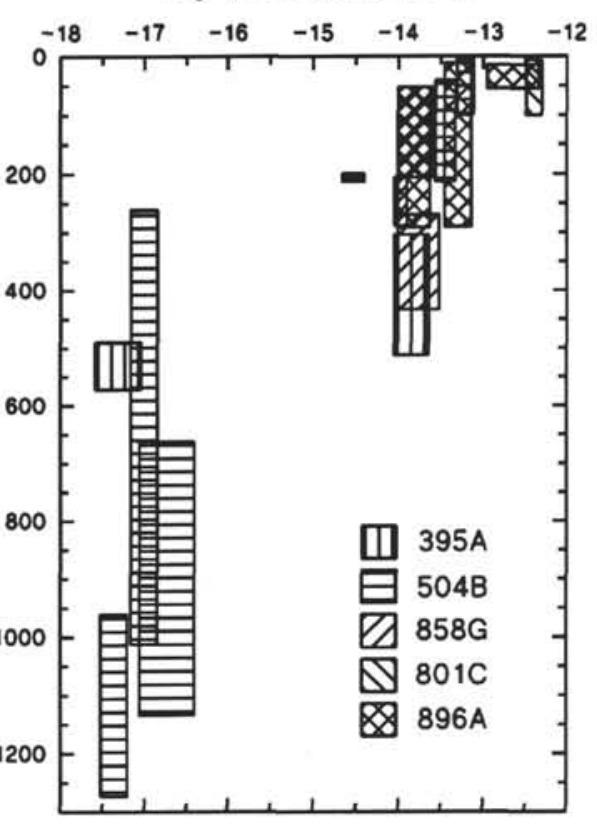

Figure 10. A. Permeabilities measured in Holes $896 \mathrm{~A}$ vs. depth into basement. B. All DSDP/ODP permeability measurements from holes that penetrate extrusive upper oceanic crust. The vertical extent of each rectangle represents the vertical interval over which the average permeability was measured; the horizontal extent represents the estimated error range in the permeability value.

ment reported in Holes 395A, 801C, and 858G, three other upper crustal holes in widely varying settings (Becker, 1990; Larson et al., 1993; Becker et al., 1994), suggesting that it may be reasonable to assume that average values of $10^{-14}$ to $10^{-13} \mathrm{~m}^{2}$ may be fairly typical of the upper oceanic crust off-axis.

Below the uppermost $200 \mathrm{~m}$ of basement, there is no indication in Hole $896 \mathrm{~A}$ of the sharp reduction by 3 orders of magnitude in permeability reported for Hole 504B by Anderson et al. (1985). Hole 896A simply does not penetrate deeply enough to resolve the question of the lateral extent of this permeability discontinuity. However, it should be pointed out that some of the apparent discontinuity may be an artifact of the differences in test equipment and in the treatment of compressibility in analyzing slug test results. For the earlier measurements in Hole 504B, Anderson et al. (1985) employed a different packer and used the compressibility of pure seawater in the calculations of transmissivity and compressibility. On the other hand, subsequent slug tests in both Holes 504B (Becker, 1989) and 896A (this paper) have been conducted with the packer system described herein, following the recommendations of Neuzil (1982), with determinations of effective compressibilities to which the calculated transmissivities and bulk permeabilities are directly proportional. The effective compressibilities for packer experiments conducted in relatively impermeable sections of the oceanic crust have typically been about one-half to a full order of magnitude greater than the value of pure seawater (Becker, 1989, 1991; S. Hickman, unpubl. data). Thus, given the differences in procedures, the very low permeability value reported by Anderson et al. (1985) below 536 mbsf in Hole 504B should not be directly compared on a plot like Figure 2 to subsequent measurements deeper in Hole 504B or in Hole 896A.

Becker (1989) first noted this inconsistency, and also noted that the DSDP rig floor records for the experiments reported by Anderson et al. (1985) did not contain the information necessary to calculate an effective compressibility. If the effective compressibility for the DSDP experiments were indeed greater than the value of seawater to the degree that effective compressibilities have been measured to be greater for all packer experiments in ODP, then the low value reported by Anderson et al. (1985) should be shifted by up to 1 order of magnitude toward higher permeabilities on a plot like Figure 2.

In fact, there may be additional information available in the record of an injection test attempted by Anderson et al. (1985) after their slug tests, but discounted "when the packer seat against the well bore was weakened by the high formation temperatures $\left(<100^{\circ} \mathrm{C}\right.$ at the packer inflation depth), and leakage occurred at pressures higher than about 20 bars above hydrostatic." Despite this disclaimer, the data from this injection test appear reasonable in quality (Fig. 11), and do not show evidence of serious leakage. When processed in the same manner as the injection tests in Hole 896A reported herein, the injection and shut-in data yield permeabilities of about $1.5-7.5 \times 10^{-16} \mathrm{~m}^{2}$, roughly 1 order of magnitude greater than the value derived by Anderson et al. from their slug tests.

Figure 12 illustrates the dilemma, which unfortunately cannot be resolved unless Hole 504B is revisited with a packer capable of isolating several hundred meters between two inflation elements. If the original interpretation by Anderson et al. (1985) is indeed correct, then the presence of such a sharp permeability discontinuity within the extrusive rocks must be explained and accommodated in models of off-axis hydrothermal circulation. If, in fact, the real permeability for the Anderson et al. interval is 1 order of magnitude higher, as indicated by the injection test analyzed herein, then the bulk permeability profiles in Holes 504B and 896A might better be represented as gradients through the extrusive section.

\section{ACKNOWLEDGMENTS}

The permeability measurements reported here would not have been possible without the expertise and hard work of the SEDCO core technicians, W. Lee and T. McCown, and the SEDCO drill crew under the supervision of the drilling superintendent R. Caldow. Several years ago, Roger Anderson graciously shared the records of ear- 
lier packer experiments in Hole 504B that are reinterpreted herein. This report was improved after careful review by Stephen Hickman. This study was supported by USSAC under JOI-USSSP Account No. 148-20732.

\section{REFERENCES}

Alt, J.C., Kinoshita, H., Stokking, L.B., et al., 1993. Proc. ODP, Init. Repts., 148: College Station, TX (Ocean Drilling Program).

Anderson, R.N., and Zoback, M.D., 1982. Permeability, underpressures, and convection in the oceanic crust near the Costa Rica Rift, eastern equatorial Pacific. J. Geophys. Res., 87:2860-2868.

Anderson, R.N., Zoback, M.D., Hickman, S.H., and Newmark, R.L., 1985. Permeability versus depth in the upper oceanic crust: in situ measurements in DSDP Hole 504B, eastern equatorial Pacific. J. Geophys. Res., 90:3659-3669.

Becker, K., 1986. Special report: development and use of packers in ODP. JOIDES J., 12:51-57.

1988. A guide to ODP tools for downhole measurements. ODP Tech. Note, 10.

1989. Measurements of the permeability of the sheeted dikes in Hole 504B, ODP Leg 111. In Becker, K., Sakai, H., et al., Proc. ODP, Sci. Results, 111: College Station, TX (Ocean Drilling Program), 317325 .

1990. Measurements of the permeability of the upper oceanic crust at Hole 395A, ODP Leg 109. In Detrick, R., Honnorez, J., Bryan, W.B., Juteau, T., et al., Proc. ODP, Sci. Results, 106/109: College Station, TX (Ocean Drilling Program), 213-222.

1991. In-situ bulk permeability of oceanic gabbros in Hole 735B, ODP Leg 118. In Von Herzen, R.P., Robinson, P.T., et al., Proc. ODP, Sci. Results, 118: College Station, TX (Ocean Drilling Program), 333347

Becker, K., Langseth, M.G., and Hyndman, R.D., 1984. Temperature measurements in Hole 395A, Leg 78B. In Hyndman, R.D., Salisbury, M.H., et al., Init. Repts. DSDP, 78B: Washington (U.S. Govt. Printing Office), 689-698.

Becker, K., Langseth, M.G., Von Herzen, R.P., and Anderson, R.N., 1983. Deep crustal geothermal measurements, Hole 504B, Costa Rica Rift. J. Geophys. Res., 88:3447-3457.

Becker, K., Morin, R.H., and Davis, E.E., 1994. Permeabilities in the Middle Valley hydrothermal system measured with packer and flowmeter experiments. In Mottl, M.J., Davis, E.E., Fisher, A.T., and Slack, J.F. (Eds.), Proc. ODP, Sci. Results, 139: College Station, TX (Ocean Drilling Program), 613-626.

Bredehoeft, J.D., and Papadopulos, S.S., 1980. A method for determining the hydraulic properties of tight formations. Water Resour. Res., 16:223238.

Cooper, H.H., Jr., Bredehoeft, J.D., and Papadopulos, I.S., 1967. Response of a finite diameter well to an instantaneous charge of water. Water Resour. Res., 3:267-269.

Coyle, B.J., and Zoback, M.D., 1988. In situ permeability and fluid pressure measurements at $\sim 2 \mathrm{~km}$ depth in the Cajon Pass research well. Geophys. Res. Lett., 15:1029-1032.

Fisher, A.T., and Becker, K., 1995. The correlation between seafloor heat flow and basement relief: observational and numerical examples and implications for upper crustal permeability. J. Geophys. Res., 100: $12641-12657$.

Fisher, A.T., Becker, K., and Narasimhan, T.N., 1994. Off-axis hydrotherma circulation: parametric tests of a refined model of processes at DSDP/ ODP site 504. J. Geophys. Res., 99:3097-3121.

Fisher, A., Becker, K., Narasimhan, T.N., Langseth, M., and Mottl, M. 1990. Passive, off-axis convection on the southern flank of the Costa Rica Rift. J. Geophys. Res., 95:9343-9370.

Gartling, D.K., 1977. Convective heat transfer analysis by the finite element method. Comput. Methods Appl. Mech. Eng., 12:365-382.

Hickman, S.H., Langseth, M.G., and Svitek, J.F., 1984. In situ permeability and pore-pressure measurements near the Mid-Atlantic Ridge, Deep Sea Drilling Project Hole 395A. In Hyndman, R.D., Salisbury, M.H., et al., Init. Repts. DSDP, 78B: Washington (U.S. Govt. Printing Office), 699708.

Horner, D.R., 1951. Pressure build-up in wells. Proc. Third World Pet. Congr., 2:501.

Hyndman, R.D., Von Herzen, R.P., Erickson, A.J., and Jolivet, J., 1976. Heat flow measurements in deep crustal holes on the Mid-Atlantic Ridge. $J$. Geophys. Res., 81:4053-4060.

Langseth, M.G., Mottl, M.J., Hobart, M.A., and Fisher, A., 1988. The distribution of geothermal and geochemical gradients near Site 501/504: implications for hydrothermal circulation in the oceanic crust. In Becker, K., Sakai, H., et al., Proc. ODP, Init. Repts., 111: College Station, TX (Ocean Drilling Program), 23-32.

Larson, R.L., Fisher, A.T., Jarrard, R.D., Becker, K., et al., 1993. Highly permeable and layered Jurassic oceanic crust in the western Pacific. Earth Planet. Sci. Lett., 119:71-83.

Matthews, C.S., and Russell, D.G., 1967. Pressure Build-up and Flow Tests in Wells. Soc. Pet. Eng., AIME, Monogr. 1.

Morin, R.H., Hess, A.E., and Becker, K., 1992. In situ measurements of fluid flow in DSDP Holes 395A and 534A: results from the DIANAUT program. Geophys. Res. Lett., 19:509-512.

Morin, R.H., Hess, A.E., and Paillet, F.L., 1988. Determining the distribution of hydraulic conductivity in a fractured limestone aquifer by simultaneous injection and geophysical logging. Ground Water, 26:587-595.

Neuzil, C.E., 1982. On conducting the modified "slug" test in tight formations. Water Resour. Res., 18:439-441.

Papadopulos, S.S., Bredehoeft, J.D., and Cooper, H.H., 1973. On the analysis of "slug test" data. Water Resour. Res., 9:1087-1089.

Parsons, R.W., 1966. Permeability of idealized fractured rock. Soc. Pet. Eng. J., 6:126-136.

Pezard, P.A., Anderson, R.N., Ryan, W.B.F., Becker, K., Alt, J.C., and Gente, P., 1992. Accretion, structure, and hydrology of intermediate spreading-rate oceanic crust from drillhole experiments and seafloor observations. Mar. Geophys. Res., 14:93-123.

Snow, D.T., 1968. Rock fracture spacing, openings and porosities. J. Soil Mech. Found. Div., Am. Soc. Civ. Eng. Proc., 94.

Sverdrup, H.U., Johnson, M.W., and Fleming, R. (Eds.), 1942. The Oceans: Their Physics, Chemistry and General Biology: Englewood Cliffs, NJ (Prentice-Hall).

Date of initial receipt: 12 August 1994

Date of acceptance: 17 February 1995 Ms 148SR-135 
A

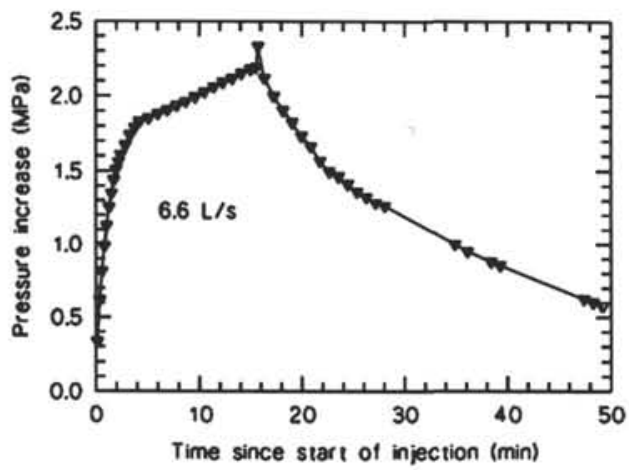

B

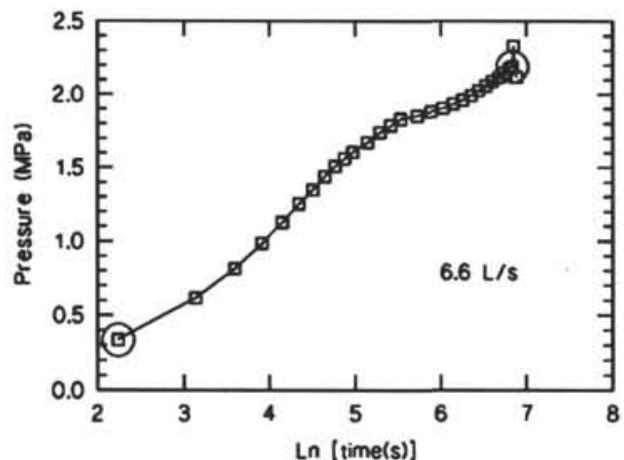

C

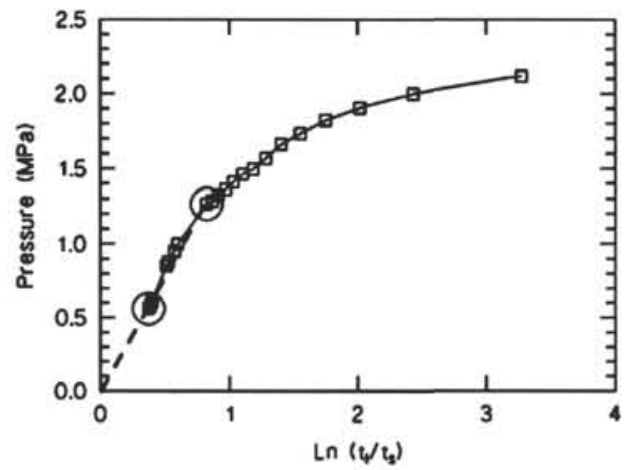

Figure 11. Results of processing the injection test conducted by Anderson et al. (1985) in Hole 504B, with a packer set at $261.5 \mathrm{~m}$ into basement when the hole extended $1012 \mathrm{~m}$ into basement, well into the sheeted dikes. A. Pressures measured in the go-devil during the injection test and subsequent shutin period. B. Rise of pressures during injection vs. In time since beginning of injection. C. Decay of pressures in the shut-in hole after injection was ended. For both Figures $10 \mathrm{~B}$ and 10C, the circles denote the end points selected for the linear segments; permeability was calculated from the slopes of these linear segments, which were obtained by linear regression.
Log \{permeability $\left(\mathrm{m}^{2}\right)$ \}

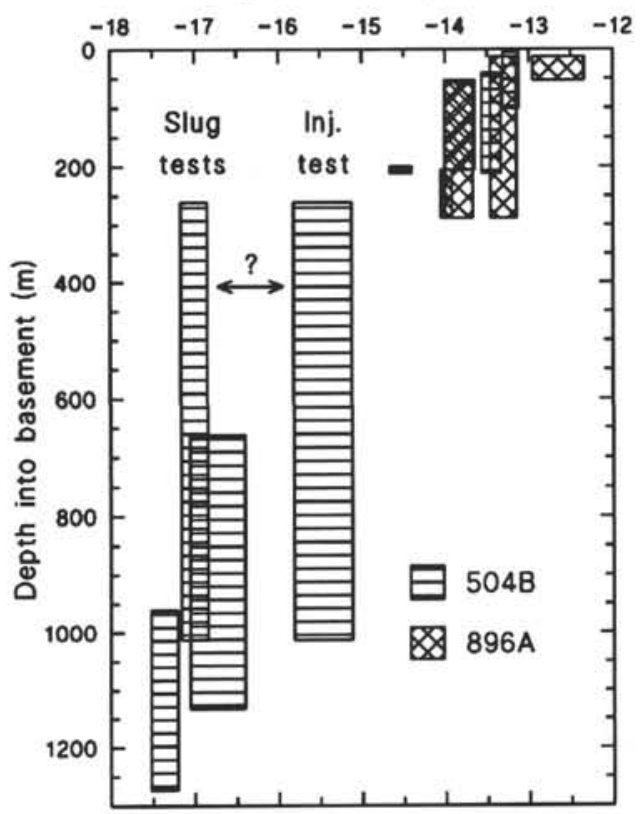

Figure 12. Comparison of permeabilities measured in Hole 896A with previous results in nearby Hole504B, including a previously unprocessed injection test deep in Hole 504B. See the last paragraph of "Discussion and Conclusions" for discussion. 